\title{
Using local knowledge and camera traps to investigate occurrence and habitat preference of an Endangered primate: the endemic dryas monkey in the Democratic Republic of the Congo
}

\author{
Daniel Alempijevic, John A. Hart, Terese B. Hart and Kate M. Dethiler
}

\begin{abstract}
The Endangered dryas monkey Cercopithecus dryas, endemic to the Democratic Republic of the Congo, is one of Africa's most enigmatic primates. The discovery of a dryas monkey killed by a hunter in the buffer zone of Lomami National Park in 2014 prompted field research on the species' distribution, habitat use and stratum preference. We used local knowledge to determine the distribution of this species and to select sites for camera-trap surveys in Lomami National Park and its buffer zone. We employed a multi-strata (o-29 m) camera-trap placement technique to determine habitat use at Camp Bartho in Lomami National Park and Bafundo Forest in the Park's buffer zone. We confirmed the occurrence of the dryas monkey at seven locations over a total area of $3,453 \mathrm{~km}^{2}$, in both the Park and its buffer zone. Dryas monkeys were detected most frequently ( 2.22 events/10o trap-days) in disturbed areas of Bafundo Forest and less in mature forest in Camp Bartho (o.82 events/10o trap-days). Dryas monkeys appear to prefer structurally complex understories and forest edges. We found that camera traps at 2-10 $\mathrm{m}$ above ground over at least 365 trapdays are required to determine if the species is present. We recommend utilizing local knowledge and using this species-specific camera-trap method in other areas of the central Congo basin to determine the wider distribution of the dryas monkey.
\end{abstract}

Keywords Camera trap, canopy research, Cercopithecus dryas, Chlorocebus, Democratic Republic of the Congo, disturbance, dryas monkey, Lomami National Park

Supplementary material for this article is available at doi.org/10.1017/So030605320000575

\section{Introduction}

\footnotetext{
lthough Ernst Schwarz described the dryas monkey Cercopithecus dryas in 1932, it remains one of Africa's most enigmatic primates. Poor documentation of

Daniel Alempijevic (10 orcid.org/0000-0002-0468-4679) and Kate M. Detwiler (Corresponding author, (D) orcid.org/0000-0003-4597-133X) Florida Atlantic University, 777 Glades Rd, Boca Raton, 33431, USA. E-mail kdetwile@fau.edu

John A. Hart (D orcid.org/0000-0002-5800-0156) and Terese B. Hart Frankfurt Zoological Society, Tshuapa-Lomami-Lualaba Project, Kinshasa, Democratic Republic of the Congo

Received 6 January 2020. Revision requested 13 March 2020. Accepted 16 June 2020. First published online 20 April 2021.
}

the type locality, description of Cercopithecus salongo as a new species, and lack of specimens have led to taxonomic confusion (Schwarz, 1932; Dandelot, 1971; Thys van den Audenaerde, 1977; Kuroda et al., 1985; Groves, 2001). Cercopithecus salongo specimens were eventually determined to be the adult of the juvenile $C$. dryas type specimen (Colyn et al., 1991), although this remains disputed (Sarmiento, 2000; Kingdon, 2015). Recent genomic studies have confirmed that the dryas monkey is a sister lineage to savannah monkeys of the genus Chlorocebus, suggesting the Cercopithecus group is paraphyletic (Guschanski et al., 2013; van der Valk et al., 2020). Here we accept Chlorocebus as the appropriate generic affiliation, pending further analyses of available specimens, and accept salongo as a junior synonym of dryas (Gilbert et al., in press). The dryas monkey's status as the only representative of the Chlorocebus clade found in lowland rainforest highlights its high conservation value as an evolutionarily significant lineage.

The dryas monkey was formerly thought to be a localized relict species, known only from a single population in the Luo Scientific Reserve, Iyondji Community Bonobo Reserve, Kokolopori Bonobo Reserve and forest near Djombolanda Village in Tshuapa Province, Democratic Republic of the Congo (Fig. 1; Kuroda et al., 1985; Lokasola, 2008; Sakamaki et al., 2016; A. Lokasola, pers. comm., 2016). This small range justified the categorization of the species as Critically Endangered (Hart et al., 2008). However, new information about the dryas monkey's range was reported in 2014, when field assistants from the TL2 Project (named after the landscape between the rivers Tshuapa, Lomami and Lualaba) documented two dryas monkeys killed by hunters in Bafundo Forest, Maniema Province, $400 \mathrm{~km}$ south-east of the species' known range (Hart, 2014). This range expansion justified a recategorization of the dryas monkey as Endangered, and emphasized the need for field studies (Hart et al., 2019).

A limiting factor for investigating the distribution of the dryas monkey is that it is difficult to detect. The TL2 Project did not detect the dryas monkey during the first 7 years of biodiversity surveys, despite documenting 10 other primate species (Hart et al., 2012). Dryas monkeys are primarily reported in secondary forest thickets (Kuroda et al., 1985; Lokasola, 2014). Kuroda et al. (1985) encountered dryas monkeys in the understorey and feeding on the ground, but 


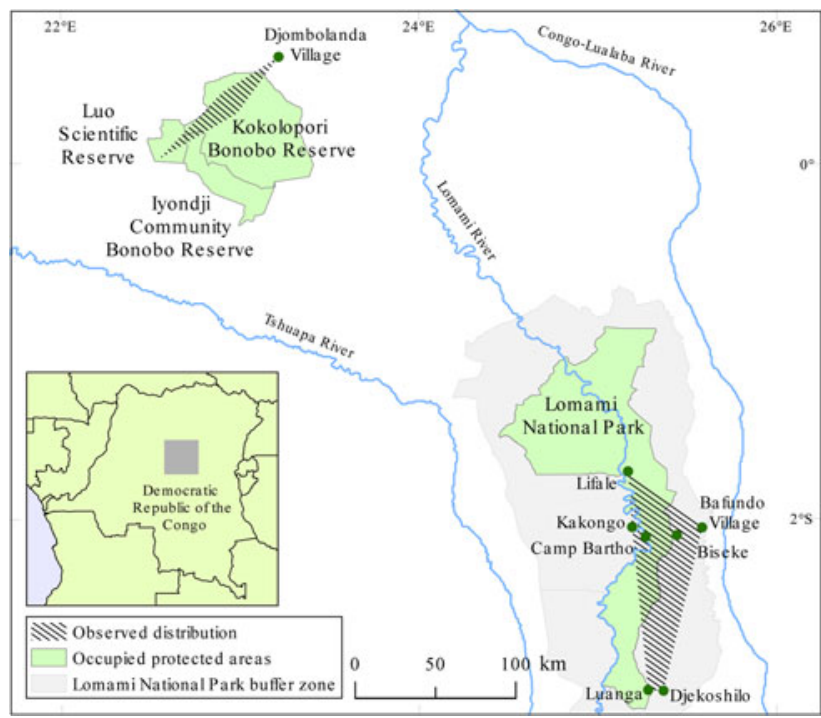

FIG. 1 The global distribution of the dryas monkey Chlorocebus dryas, endemic to the Democratic Republic of the Congo, indicating the location of the Luo-Djombolanda population (Luo Scientific Reserve, Iyondji Community Bonobo Reserve, Kokolopori Bonobo Reserve, Djombolanda Forest) and the Lomami National Park and buffer zone population. Specific locations where dryas monkeys have been observed in Lomami National Park and its buffer zone are labeled.

surveys using camera traps placed at ground level in Iyondji Community Bonobo Reserve and Lomami National Park and its buffer zone failed to detect them (Sakamaki et al., 2016; J.A. Hart et al., unpubl. data). Although camera traps are widely used to detect and survey cryptic species, it is necessary to develop specific camera-trap placements that could reliably detect dryas monkeys.

Local knowledge has been shown to provide useful information on understudied and cryptic species (Cano \& Tellería, 2013; Nguyen et al., 2019). We therefore solicited information on the dryas monkey from residents of villages in the Lomami National Park's buffer zone to determine the distribution of the dryas monkeys and select sites for camera-trap surveillance. We then used camera traps to document stratum and habitat preference and estimate the relative abundance of the dryas monkey at two sites, one each in Lomami National Park and its buffer zone. Specifically, we tested the following hypotheses: dryas monkeys (1) prefer the understorey-mid canopy strata, (2) prefer disturbed patches over mature forest, and (3) would be detected more frequently in Lomami National Park than in its buffer zone, where hunting is more common. We also developed a species-specific camera-trap method to detect the species.

\section{Study area}

This study involved two field surveys: Phase I (October 2016-July 2017) and Phase II (August 2017-March 2018) at

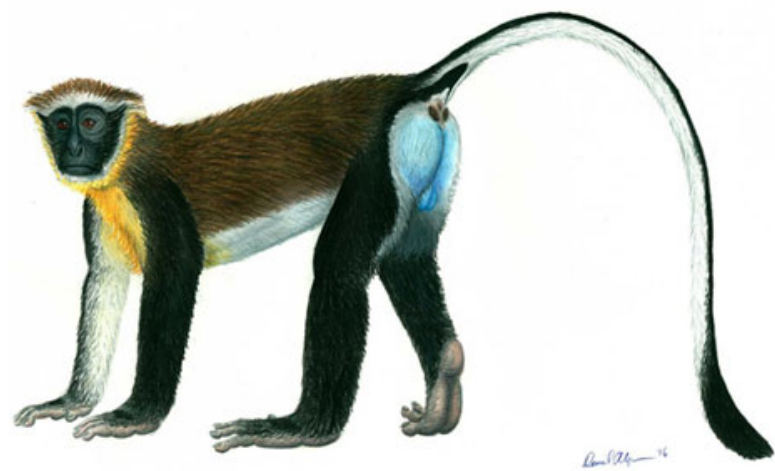

Fig. 2 Illustration of an adult male dryas monkey Chlorocebus dryas, drawn from photographs of an individual killed by a hunter in the Bafundo Forest, for use in educational material distributed in local communities, to help bio-monitoring patrol teams inform people of the protected status of the inoko, and to solicit information on the occurrence of the species.

two sites in Lomami National Park and its buffer zone in Maniema Province, Democratic Republic of the Congo. Lomami National Park encompasses $8,874 \mathrm{~km}^{2}$ of lowland rainforest and savannah bisected by the Lomami River. The Park was established in 2016 and with its buffer zone covers c. $29,000 \mathrm{~km}^{2}$ in the TL2 Landscape. The landscape has $<150$ villages, the residents of which practice shifting agriculture, fishing and hunting in the Park's buffer zone.

We selected Bafundo Forest in the buffer zone for camera-trap surveillance, starting at the location where the first reported dryas monkey was killed by a hunter. This forest was the site of Bafundo Village during 1935-1956, before its residents moved to their current location $3 \mathrm{~km}$ to the south-west. We established the second survey site $40 \mathrm{~km}$ west of Bafundo Village, at Camp Bartho in Lomami National Park after a ranger patrol team saw a dryas monkey there in 2014. Camp Bartho was occupied by one family during 2006-2013 and included five dwellings and several gardens. Since then, the family moved their camp to the west bank of the Lomami River, outside the Park.

\section{Methods}

\section{Distribution}

We created a dryas monkey illustration matching the pelage of the adult male specimen killed in Bafundo Forest (Fig. 2). We used it to create a poster that invited people to come forward with information about sightings of the species, locally known as inoko. We conducted informal interviews opportunistically when an informant volunteered information. We distributed the poster in villages and incorporated it into the species identification material used by patrol teams. We trained the teams in species identification and 


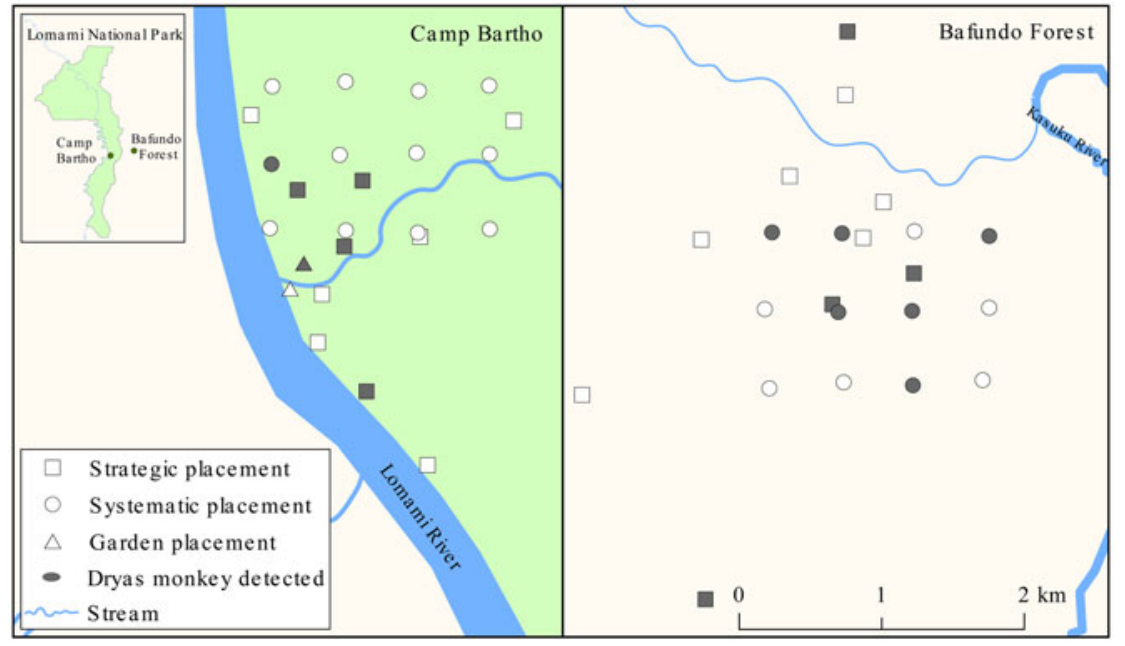

FIG. 3 The spatial relationship between sampling points in the strategic and systematic surveys, and the distribution of dryas monkey detections at the Camp Bartho and Bafundo Forest survey sites. equipped them with cameras to take photographs of any dryas monkeys seen during patrols. If a patrol team encountered a dryas monkey or if one killed by a hunter was photographed, we considered these as confirmed occurrences (Hart, 2019).

\section{Camera-trap survey design}

We developed a multi-strata camera-trap technique with a placement of three camera traps at each survey point, one each monitoring the ground, understorey and canopy. We positioned the camera traps on game paths $(0.2-0.5 \mathrm{~m}$ above ground), shrubs and liana tangles (1.5-10.0 m), and horizontal limbs (14.9-29.0 m) forming pathways to adjacent tree crowns (Gregory et al., 2014). We used the singlerope technique to access the canopy, and the double-rope technique to move to the desired camera-trap location when needed (Maher, 2010).

We used 55 Bushnell (Overland Park, USA) camera traps (models Trophy Cam 119636, Trophy Cam 119736, Trophy Cam Aggressor 119774, Essential E3 119837). We programmed them to take 6o-second high-quality videos over a 24-hour period using high sensitivity and a 1-second rest period.

Phase I was a strategic survey to increase our chances of detecting dryas monkeys, using 20 camera-trap placements in Bafundo Forest and Camp Bartho (Fig. 3). We set placements in locations where informants had seen dryas monkeys, or in areas with a dense understorey, where informants had indicated dryas monkeys prefer to forage. We set two additional camera traps in the understorey at the edge of a recently abandoned garden at Camp Bartho.

Phase II was a systematic survey, to eliminate bias in detection rates, in Bafundo Forest and Camp Bartho. We selected 24 sampling points $500 \mathrm{~m}$ apart in $1.5 \mathrm{~km}^{2}$-grid cells
(Fig. 3). The mean distance of each camera-trap placement to the pre-determined sampling point was $23.8 \mathrm{~m} \pm \mathrm{SD} 13.2 \mathrm{~m}$.

\section{Video processing and analysis}

We grouped videos into an event if $\leq 30$ minutes passed between dryas monkey videos from the same camera trap. We grouped trap-days per stratum to compare trap effort between strata. Trap-days are the total number of days a camera trap was functional in the field. If a camera trap was not functioning when we retrieved it, we considered the date and time of the last video recorded as the last trap-day.

We calculated the dryas monkey detection rate per stratum (dryas monkey events/camera-trap days $\times 100$ ) to compare events across surveys with different trap effort. To determine if dryas monkeys show preference for a particular stratum, we compared detections per stratum between sites and surveys using the Kruskal-Wallis rank sum test. To calculate the minimum trap effort required to detect a dryas monkey from our data, we determined the probability distribution of time between events by fitting the observed detection rates to a Poisson point process for each survey (Supplementary Fig. 1).

\section{Habitat modeling}

To create a predictive model of dryas monkey habitat preference, we considered six a priori covariates. As both local knowledge and previous studies indicated dryas monkeys prefer disturbed sites (Kuroda et al., 1985; Lokasola, 2014), we recorded covariates related to forest structure in a 20-m diameter plot at all 24 sampling points in Phase II. We recorded per cent canopy cover, canopy height, and understorey complexity (the number of times vegetation touched a $5-\mathrm{m}$ vertical pole; modified from Suarez-Rubio et al., 2018) at 5 and $10 \mathrm{~m}$ height in the 4 cardinal directions from the sampling point, recorded the number of trees and 
TABLE 1 Data on the occurrence of the dryas monkey Chlorocebus dryas collected opportunistically during patrols in Lomami National Park and its buffer zone, Democratic Republic of the Congo (Fig. 1).

\begin{tabular}{lll}
\hline Location & Verification & Year \\
\hline Lifale & Patrol observation; photograph & 2019 \\
Kakongo & Patrol observation & 2018 \\
Luanga & Hunter kill; photograph & 2018 \\
Djekoshilo & Patrol observation & 2018 \\
Biseke & Patrol observation & 2018 \\
Camp Bartho & Patrol observation; camera trap & 2014 \\
Bafundo Forest & Hunter kill; camera trap & 2014 \\
\hline
\end{tabular}

their diameter at breast height $(\mathrm{DBH} ;>10 \mathrm{~cm})$, and noted the presence or absence of fallow fields. We examined any potential differences in habitat characteristics between Bafundo Forest and Camp Bartho using a multivariate analysis of variance.

We used logistic regression to model the presence/absence of dryas monkeys at camera-trap sampling points as a function of habitat covariates. We did not record DBH, number of trees, or understorey complexity during Phase I, and therefore we used the mean values from Phase II for these variables. To avoid problems associated with collinearity between covariates, we used variable inflation factors calculated with the ISLR 2.1 package in $R$ 3.6.1 ( $\mathrm{R}$ Core Team, 2019). Covariates with a variable inflation factor $>10$ were excluded from the model. We determined the covariate(s) that had the most predictive power from the global model, from which we selected the covariate(s) with the lowest Akaike's information criterion (AIC) score and $\mathrm{P} \leq 0.05$. We analysed variation between the null and residual deviance using analysis of variance. To evaluate candidate models, we calculated AIC corrected for small sample size (AICc) and maximum likelihood values using the MuMin 1.43.6 package, to determine the fit of the global model and select the most parsimonious model. We examined the relative importance of each variable using the per-variable sum of model weights. We determined variable importance based on the predictive power of each variable in the model, and then calculated the probability of detecting dryas monkeys for the important variables.

\section{Results}

We confirmed seven occurrences of dryas monkeys in Lomami National Park and its buffer zone during 20142019 based on opportunistic reports provided by local residents and park patrols (Table 1). Observations were confirmed in the edge of gallery forest, at sites of current or historical anthropogenic activity, and in an area of natural liana abundance in mature forest (Supplementary
TABLE 2 Frequency of detection of dryas monkeys in the forest understorey $(1.5-10 \mathrm{~m})$ and the estimated minimum trap effort required for a $95 \%$ probability of detecting the species, using camera traps in the Phase I and Phase II surveys (see text for details and Fig. 1) in Bafundo Forest and Camp Bartho.

\begin{tabular}{llll}
\hline Survey & Survey design & $\begin{array}{l}\text { Detection } \\
\text { frequency }^{1}\end{array}$ & $\begin{array}{l}\text { Minimum } \\
\text { trap effort }^{2}\end{array}$ \\
\hline Bafundo Forest I & Strategic & 1.67 & 179.28 \\
Bafundo Forest II & Systematic & 2.22 & 135.02 \\
Camp Bartho I & Strategic & 0.82 & 364.45 \\
Camp Bartho II & Systematic & 0.28 & $330.95^{3}$ \\
\hline
\end{tabular}

${ }^{1}$ Number of events per 100 trap days.

${ }^{2}$ Trap effort (camera-trap days) required to be $95 \%$ certain a dryas monkey will be detected if present at a site.

${ }^{3}$ Actual trap effort accumulated before detecting a dryas monkey in the survey.

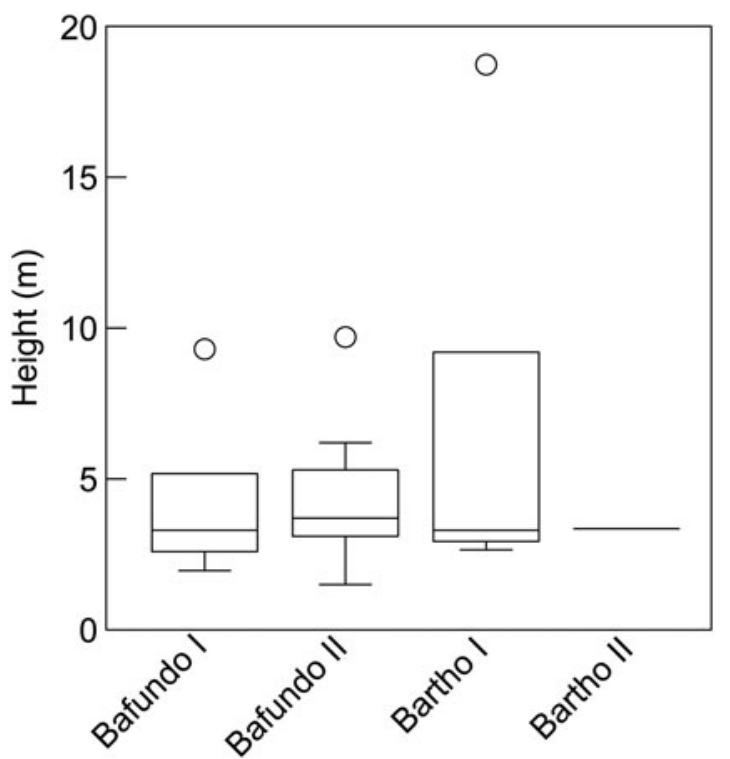

FIG. 4 The height above ground at which dryas monkeys were detected by camera traps in strategic (I) and systematic (II) surveys in the Bafundo Forest and Camp Bartho. The boxes represent the median height with upper and lower quartiles where dryas monkeys were detected (25\% greater and $25 \%$ lesser than the median); whiskers represent maximum/minimum values, and circles outliers.

Fig. 2). The dryas monkey's range (its extent of occurrence) in Lomami National Park and its buffer zone is $3,453 \mathrm{~km}^{2}$ (Fig. 1).

Camera traps detected dryas monkeys at both sites and in both surveys (Plate 1). Detection frequencies were higher in Bafundo Forest than in Camp Bartho. The minimum number of days of accumulated trap effort required for a $95 \%$ certainty of detecting dryas monkeys was $135-365$ (Table 2). 
TABLE 3 Comparison of six habitat characteristics of Bafundo Forest and Camp Bartho, with the mean and standard deviation of each covariate per site, and the $\mathrm{F}$ and $\mathrm{P}$ values from the multivariate analysis of variance.

\begin{tabular}{|c|c|c|c|c|}
\hline Characteristic & Bafundo Forest & Camp Bartho & $\mathrm{F}$ & $\mathrm{P}$ \\
\hline Mean \pm SD diameter at breast height $(>10 \mathrm{~cm})$ & $27.04 \pm 10.91$ & $25.07 \pm 4.11$ & 0.21 & \\
\hline Mean \pm SD tree density $(>10 \mathrm{~cm})$ & $9.75 \pm 4.73$ & $20.58 \pm 4.38$ & 32.12 & $* *$ \\
\hline Mean \pm SD $\%$ canopy cover & $38.20 \pm 16.25$ & $46.45 \pm 11.89$ & 1.75 & \\
\hline Mean \pm SD canopy height $(m)$ & $18.35 \pm 8.47$ & $18.12 \pm 5.51$ & 0.13 & \\
\hline Mean \pm SD understorey complexity ${ }^{1}$ & $49.67 \pm 17.57$ & $31.00 \pm 10.36$ & 11.75 & * \\
\hline Mean \pm SD fallow fields (presence/absence) & $0.83 \pm 0.39$ & $0.25 \pm 0.45$ & 14.41 & * \\
\hline
\end{tabular}

${ }^{*} \mathrm{P}<0.05 ;{ }^{* *} \mathrm{P}<0.01$.

${ }^{1}$ Number of times vegetation touched a vertical pole $5 \mathrm{~m}$ in height.

Camera traps accumulated 1,742 trap-days on the ground, 2,821 trap-days in the understorey and 2,927 trap-days in the canopy. Understorey camera traps recorded 32 dryas monkey events, canopy camera traps detected a single event, and dryas monkeys were not detected by camera traps at ground level. We found no significant difference in detection height across surveys $(\mathrm{P}=0.996$; Fig. 4).

Some aspects of forest structure differed significantly between Bafundo Forest and Camp Bartho (Table 3). There were more fallow fields and the forest understorey was more complex in Bafundo Forest (Plates 2 \& 3), and tree density was significantly higher in Camp Bartho.

All six covariates had variance inflation factors $<10$, and therefore we used all covariates in the logistic model. In the global model, fallow fields was the only covariate identified as a significant predictor of dryas monkey presence (Table 4). Importance tests of the covariates in the bestfit models (Table 5; see Supplementary Material 1 for all models) indicate fallow fields was the covariate of greatest importance (0.99). The likelihood of detecting dryas monkeys on the edge of fallow fields was higher (0.67) than in mature forest (0.2).

\section{Discussion}

Our study of the dryas monkey population in Lomami National Park and its buffer zone adds to our knowledge of the distribution, stratum preference, and habitat use of this enigmatic species. Most of the new records of the species came from the knowledge of local people. People that directly depend on forest resources are often knowledgeable about local biodiversity (Gadgil et al., 2019). Even rapid, unstructured interviews can be useful, but reports need to be confirmed, as we did, with camera traps or other complementary methods (Nguyen et al., 2019).

The known distribution of dryas monkeys includes both banks of the Lomami River, a major tributary of the Congo River (Fig. 4). Therefore, the Congo River may be the only fluvial barrier to the species' distribution. No population has been confirmed west of the Tshuapa River, despite

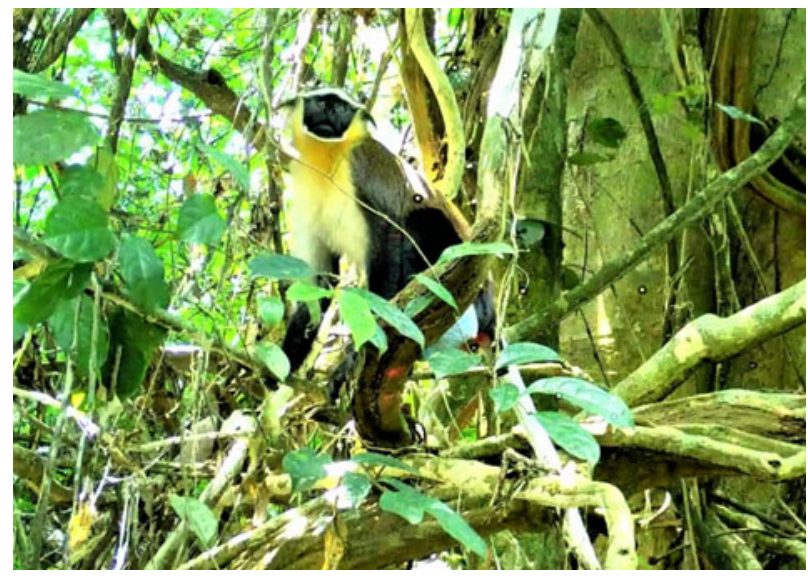

Plate 1 Still-frame from a camera-trap video of an adult male dryas monkey Chlorocebus dryas in Bafundo Forest in the buffer zone of Lomami National Park (Fig. 1).

assumptions that the species occurs further to the west in Salonga National Park (Thys van den Audenaerde, 1977). Kingdon's (2015) suggestion that dryas monkeys could occur at more westerly localities south of the Congo River needs to be investigated with further surveys.

Our camera-trap placements detected dryas monkeys almost exclusively in the understorey across all surveys, regardless of canopy structure, supporting our hypothesis that the species prefers the understorey-mid canopy strata. A few monkeys were recorded descending out of view towards the ground. Dryas monkeys have been seen foraging on Aframomum and Megaphrynium (Kuroda et al., 1985; Kingdon, 2015), both abundant herbs in fallow fields in the Bafundo Forest (Plate 3). However, as the camera traps on the ground did not detect dryas monkeys, it seems unlikely they travel on the ground. Only one camera trap in the canopy detected a dryas monkey, suggesting they rarely travel in the upper canopy.

Dryas monkeys showed a preference for the edges of fallow fields, supporting our hypothesis that the species prefers disturbed patches over mature forest. Dryas monkeys were detected most frequently in Bafundo Forest during the Phase II survey, where we encountered the greatest area of 

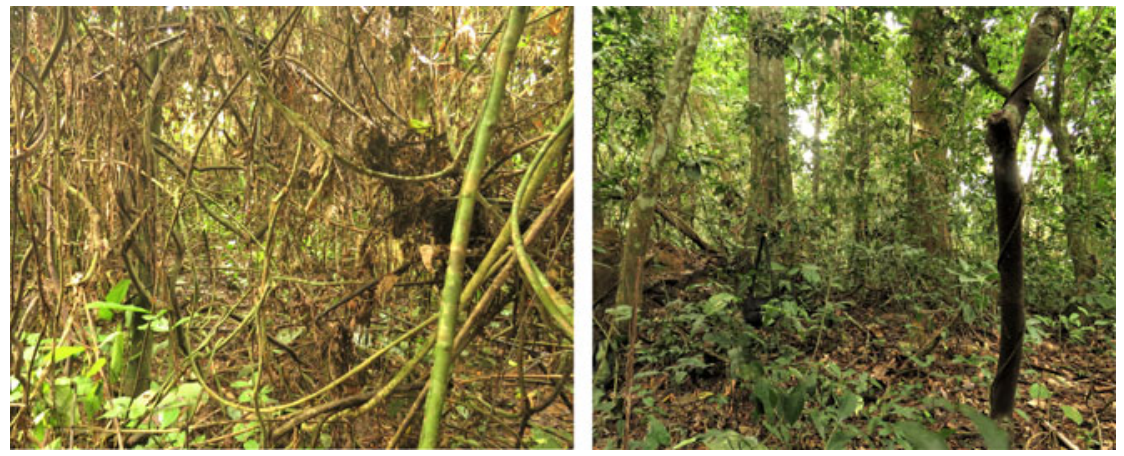

Plate 2 Understorey structure typical of fallow fields in Bafundo Forest (left) and mature forest at Camp Bartho (right) in the buffer zone and Lomami National Park, respectively.

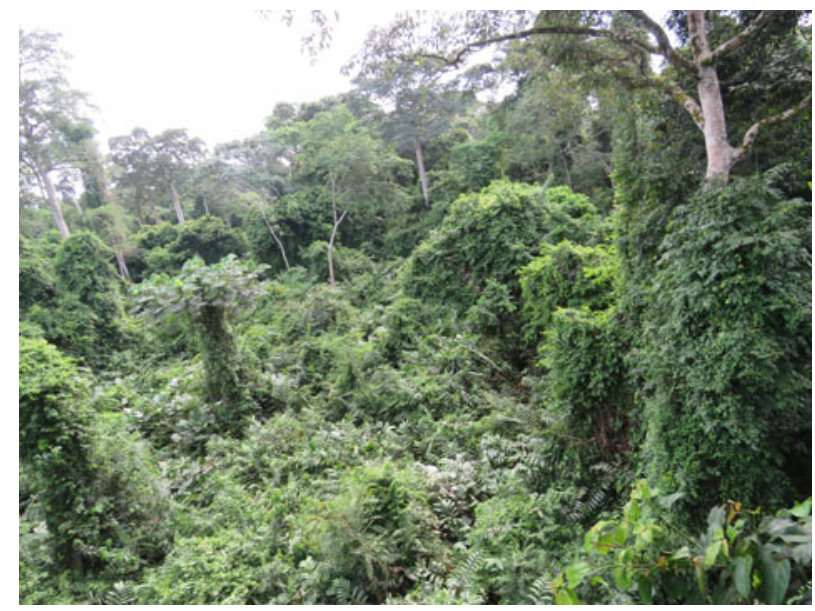

Plate 3 View from the canopy of a fallow field in Bafundo Forest, characterized by sparse trees, dense herbs, and lianas.

TABLE 4 The six covariates tested for inclusion in multivariate logistic models of habitat use by dryas monkeys at two sites in Lomami National Park and its buffer zone, selected based on literature and local ecological knowledge, with the mean and standard deviation $(\overline{\mathrm{x}} \pm \mathrm{SD})$ and probability of each covariate in the model. We collected covariate data strategically from disturbed forest where local hunters suggested dryas monkeys were likely to be encountered $(n=21)$ and systematically sampled every $500 \mathrm{~m}$ at the same sites $(\mathrm{n}=\mathbf{2 2})$.

\begin{tabular}{lrr}
\hline Covariate & $\overline{\mathrm{x}} \pm \mathrm{SD}$ & $\mathrm{P}$ \\
\hline Diameter at breast height $(>10 \mathrm{~cm})$ & $0.03 \pm 0.07$ \\
Tree density $(>10 \mathrm{~cm})$ & $0.31 \pm 0.18$ \\
\% canopy cover & $0.04 \pm 0.03$ \\
Canopy height $(\mathrm{m})$ & $-0.22 \pm 0.13$ \\
Understorey complexity & $0.14 \pm 0.07$ \\
Fallow fields (presence/absence) & $5.01 \pm 1.95$ \\
\hline
\end{tabular}

${ }^{*} \mathrm{P}<0.05$.

anthropogenic disturbance. The small (2.2-3.3 kg) body size of dryas monkeys may be adapted to living in such dense vegetation (Kuroda et al., 1985).

Some primates prefer disturbed microhabitats in otherwise mature forest (Bourlière, 1985). Two West African
TABLE 5 Habitat logistic regression models for habitat use by dryas monkeys in Camp Bartho and Bafundo Forest.

\begin{tabular}{llll}
\hline Model & $\mathrm{AICc}^{1}$ & $\Delta \mathrm{AICc}^{2}$ & $\mathrm{AICcWt}^{3}$ \\
\hline Fallow fields & 52.23 & 2.86 & 0.03 \\
Canopy height + fallow fields + tree & 50.51 & 1.14 & 0.08 \\
\begin{tabular}{l} 
density + understorey complexity \\
\hline
\end{tabular} & & & \\
\hline
\end{tabular}

${ }^{1}$ AICc, Akaike's information criterion adjusted for small sample size.

${ }^{2} \Delta \mathrm{AICc}$, difference in Akaike's information criterion adjusted for small sample size in relation to the top model.

${ }^{3} \mathrm{AICcWt}$, relative likelihood of the model adjusted for small sample size.

strepsirhines, Arctocebus calabarensis and Euoticus elegantulus, are restricted to liana-rich microhabitats (CharlesDominique, 1977). In Ituri Forest $\left(1.6711^{\circ} \mathrm{N}, 28.4874^{\circ} \mathrm{E}\right)$, Cercopithecus ascanius specializes in foraging for arthropods in forest gaps (Thomas, 1991). In Lomami National Park and its buffer zone dryas monkeys use mature forest, but prefer disturbed forest patches.

Despite being hunted in the buffer zone, dryas monkeys were mostly detected in Bafundo Forest, and thus our hypothesis that the species would be detected more in Lomami National Park than in its buffer zone was not supported by our data. It was not possible from our data to separate the effects of hunting and fallow fields, but the gains received by exploiting disturbed sites must presumably outweigh the cost of being hunted. We are not aware of any reports of dryas monkeys in local or regional bushmeat markets, and thus the species may be harvested at a lower rate than other monkey species. Local people in Bafundo Village indicated the monkey is too small to send to market and the species' preference for dense thicket makes them difficult to shoot.

Although hunting and habitat loss are causing global declines in primate populations (Estrada et al., 2017), African primates have adapted to forest edge conditions in the past during dry climatic periods (De Almeida-Rocha et al., 2017). Dryas monkeys may be exploiting disturbed patches in the Congo Basin, as Chlorocebus does along the Basin's periphery. The sightings in Djekoshilo and Luanga at the southern limit of the rainforest block are within 75 $\mathrm{km}$ of the northern range limit of Malbrouck's monkey 
Chlorocebus cynosuros (Sarmiento, 2013). The dryas monkey's use of gallery forest, and the southern extent of its range, should be explored further to determine possible sympatry between dryas and Malbrouck's monkeys.

We were able to detect the dryas monkey with our placements of three camera traps arranged vertically in different forest strata, and at least 365 trap-days are required to achieve a $95 \%$ detection probability, although dryas monkeys may be detected sooner in suitable habitat. The cameras that detected the species most frequently were those in the lower strata of the canopy and understorey, at 2$10 \mathrm{~m}$ above ground. Because foliage was dense and branches thin at 10-15 $\mathrm{m}$ above ground, this stratum was not suitable for placement of camera traps, although we observed dryas monkeys at this height (Supplementary Fig. 3).

Our findings indicate that Lomami National Park and its buffer zone contain the greatest extent of the species' known range (Fig. 1), and Lomami is the only National Park with a confirmed population. High heterozygosity and low inbreeding measures from genomic analysis of a hunter-killed dryas monkey (collected on 26 October 2014) from Bafundo Forest suggest that it was a representative of a larger contiguous population (van der Valk et al., 2020). We recommend that researchers and conservationists working in the central basin of the Democratic Republic of the Congo mobilize local knowledge to identify other areas where the dryas monkey occurs and confirm any reports using our camera trap placement technique.

Acknowledgements We dedicate this manuscript to Pablo Ayali (1981-2018) for his commitment to the dryas monkey project and the conservation of Lomami National Park. This research was funded by the Lukuru Foundation, Margot Marsh Biodiversity Foundation (001378), Mohammed Bin Zayed Species Conservation Fund (162513850), Florida Atlantic University, Primate Conservation Incorporated (1322), International Primatological Society, Dynamic Youth Community, and crowd funding. We thank Erik Noonburg and Michael Lawes for statistical support and helpful comments; Jeanne Pierre Kapale, Henri Silegowa, Aimedo Onale, Boniface Kamanya, Chief Onombe Djecko and other informants who reported dryas monkey observations; Marten Balimu, Reddi Bosisa and John I. Mponga for assistance with camera trapping; and Martin Fisher, Jef Dupain and an anonymous reviewer for their suggestions.

Author contributions Study design: DA, KD, JH, TH; fieldwork: DA; data analysis: DA; writing : DA, KD, JH, TH.

\section{Conflicts of interest None.}

Ethical standards This non-invasive research used no-flash camera traps. L'Institut Congolais pour la Conservation de la Nature granted research permission to work in Lomami National Park. The local chiefs of Bafundo, Likandjo and Bote villages and the sector chief of Maniema Province granted permission to access the forest. Florida Atlantic University's Institutional Review Board (916126-4) and the Institutional Animal Care and Use Committee (A16-27) approved our research protocol.

\section{References}

Bourlière, F.Ç. (1985) Primate communities: their structure and role in tropical ecosystems. International Journal of Primatology, 6, 1.

CAno, L.S. \& Tellería, J.L. (2013) Local ecological knowledge as a tool for assessing the status of threatened vertebrates: a case study in Vietnam. Oryx, 47, 177-183.

Charles-Dominique, P. (1977) Ecology and Behaviour of Nocturnal Primates: Prosimians of Equatorial West Africa. Gerald Duckworth \& Co Ltd, London, UK.

Colyn, M., Gautier-Hion, A. \& Thys van den Audenaerde, D.F.E. (1991) Cercopithecus dryas Schwarz 1932 and C. salongo Thys van den Audenaerde 1977 are the same species with an age-related coat pattern. Folia Primatologica, 56, 167-170.

Dandelot, P. (1971) Order primates. In The Mammals of Africa, an Identification Manual (eds J. Meester \& H.W. Setzer), p. 45. Smithsonian Institute Press, Washington, DC, USA.

De Almeida-Rocha, J.M., Peres, C.A. \& Oliveira, L.C. (2017) Primate responses to anthropogenic habitat disturbance: a pantropical meta-analysis. Biological Conservation, 215, 30-38.

Estrada, A., Garber, P.A., Rylands, A.B., Roos, C., FernandeZ-Duque, E., DiFiore, A. et al. (2017) Impending extinction crisis of the world's primates: why primates matter. Science Advances, 3, e1600946.

Gadgil, M., Berkes, F. \& Folke, C. (2019) Indigenous knowledge for biodiversity conservation. Ambio, 22, 151-156.

Gilbert, C., Gilissen, E., Arenson, J., Patel, B., Nakatsukasa, M., HART, T. et al. (in press) Morphological analysis of new dryas monkey specimens from the central Congo Basin: taxonomic considerations and an emended diagnosis. American Journal of Physical Anthropology.

Gregory, T., Carrasco Rueda, F., Deichmann, J., Kolowski, J. \& Alonso, A. (2014) Arboreal camera trapping: taking a proven method to new heights. Methods in Ecology and Evolution, 5, 443-451.

Groves, C. (2001) Why taxonomic stability is a bad idea, or why are there so few species of primates (or are there?). Evolutionary Anthropology, 10, 192-198.

Guschanski, K., Krause, J., Sawyer, S., Valente, L.M., Bailey, S., Finstermeier, K. et al. (2013) Next-generation museomics disentangles one of the largest primate radiations. Systematic Biology, 62, 539-554.

HART, T.B. (2014) Inoko and the camera trap thief. Searching for Bonobo in Congo. bonoboincongo.com/2014/10/27/inoko-andthecamera-trap-thief [accessed 18 November 2020].

Hart, T.B. (2019) Dryas monkey: Critically Endangered? Not anymore. Searching for Bonobo in Congo. bonoboincongo.com/ 2019/04/14/critically-endangered-not-anymore [accessed 18 November 2020].

Hart, J.A., Butynski, T.M. \& Hurley, M. (2008) Cercopithecus dryas. In The IUCN Red List of Threatened Species 2008: e.T4216A10645463. dx.doi.org/10.2305/IUCN.UK.2008.RLTS. T4216A10645463.en [accessed 27 November 2020].

Hart, J.A., Detwiler, K.M., Alempijevic, D., Lokasola, A. \& Rylands, A.B. (2019) Cercopithecus dryas. In The IUCN Red List of Threatened Species 2019: e.T4216A17947691. dx.doi.org/10.2305/ IUCN.UK.2019-1.RLTS.T4216A17947691.en [accessed 18 November 2020].

Hart, J.A., Detwiler, K.M., Gilbert, C.C., Burrell, A.S., Fuller, J.L., Emetshu, M. et al. (2012) Lesula: a new species of Cercopithecus monkey endemic to the Democratic Republic of Congo and implications for conservation of Congo's central basin. PLOS ONE, 7, e44271. 
KIngDon, J. (2015) The Kingdon Field Guide to African Mammals. 2nd edition. Princeton University Press, Princeton, USA.

Kuroda, S., Kano, T. \& Muhindo, K. (1985) Further information on the new monkey species, Cercopithecus salongo Thys van den Audenaerde, 1977. Primates, 26, 325-333.

Lokasola, A. (2008) First field study of the Salongo monkey (Cercopithecus dryas), Kokolopori Bonobo Reserve, DRC. In XXII Congress of the International Primatological Society, Abstract \#144. Edinburgh, UK.

Lokasola, A. (2014) Cercopithecus dryas food list, part eaten, and feeding strategy in the Kokolopori Nature Reserve. In $1 s t$ International Conference on Biodiversity in the Congo Basin, Abstract \# 228. Kisangani, Democratic Republic of the Congo.

Maher, J. (2010) The Roof of the Rainforest: ITEC Manual for Canopy Access Techniques. Tree Climber's Coalition, Atlanta, USA.

Nguyen, A., Tran, V.B., Hoang, D.M., NGuyen, T.A.M., NGuyen, D.T., Tran, V.T. et al. (2019) Silver-backed chevrotain. Nature Ecology \& Evolution, 3, 1650-1654.

R Development Core Team (2019) R: A Language and Environment for Statistical Computing. R Foundation for Statistical Computing, Vienna, Austria. R-project.org/ [accessed 25 October 2019].

Sakamaki, T., Maloueki, U., BakaA, B., Bongoli, L., Kasalevo, P., Terada, S. \& Furuichi, T. (2016) Mammals consumed by bonobos (Pan paniscus): new data from the Iyondji forest, Tshuapa, Democratic Republic of the Congo. Primates,

57, 295-301.

Sarmiento, E. (2000) The taxonomic status of Cercopithecus dryas and Cercopithecus salongo. African Primates, 4, 65-67.

Sarmiento, E. (2013) Chlorocebus cynosuros. In Mammals of Africa: Volume II Primates (eds T.M. Butynski, J. Kingdon \& J. Kalina), pp. 306-309. Bloomsbury Publishing PLC, London, UK.

Schwarz, E. (1932) Der Vertreter der Diana-Meerkatze in ZentralAfrika. Revue de Zoologie et de Botanique Africaines, 21, 251-254.

Suarez-Rubio, M., Ille, C. \& Bruckner, A. (2018) Insectivorous bats respond to vegetation complexity in urban green spaces. Ecology and Evolution, 8, 3240-3253.

Thом As, S.C. (1991) Population densities and patterns of habitat use among anthropoid primates of the Ituri Forest, Zaire. BIOTROPICA, 23, 68-83.

Thys van den Audenaerde, D.F.E. (1977) Description of a monkey skin from east-central Zaire as a probable new species. Revue de Zoologie Africaine, 91, 1000-1010.

van der Valk, T., Gonda, C.M., Silegowa, H., Almanza, S., Sifuentes-Romero, I., Hart, T.B. et al. (2020) The genome of the Endangered Dryas monkey provides new insights into the evolutionary history of the vervets. Molecular Biology and Evolution, 37, 183-194. 